Jurnal Olahraga \& Kesehatan Indonesia

Volume 1 Nomor 1 (2020)

E-ISSN: 2747-061X

available online at https://jurnal.stokbinaguna.ac.id/index.php/jok

\title{
HASIL BELAJAR PADA MASA PANDEMI \\ MELALUI MODEL STUDENT FACILITATOR AND EXPLAINING
}

\author{
Muhammad Irvan Ramadan Singarimbun ${ }^{1}$, Khairul Usman ${ }^{2}$ *
}

${ }^{1}$ SMA Swasta Muhammadiyah Kabanjahe, Sumatera Utara, 22151, Indonesia.

${ }^{2}$ Universitas Negeri Medan, Sumatera Utara, 20221, Indonesia.

*Coressponding Author: khairulusman.binaguna@gmail.com

\begin{tabular}{c}
\hline Keterangan \\
\hline Rekam Jejak: \\
Received, Oktober 2020 \\
Revised, November 2020 \\
Accepted, Desember 2020 \\
\hline Kata Kunci: \\
Hasil Belajar, Masa \\
Pandemi, Model Student \\
Facilitator and Explaining
\end{tabular}

Pandemi, Model Student
Facilitator and Explaining
Penelitian ini merupakan penelitian tindakan (Action Research) yang dikebangkan pada aspek pendidikan yaitu menjadi Penelitian Tindakan Kelas (PTK). Model tindakan Action Research yang digunakan adalah Model Spiral dari Kemmis dan Taggart. Model Spiral dari Kemmis dan Taggart adalah model yang realisasinya menggunakan istilah Plan, Act, Observe, dan Reflect (Suharsaputra, 2018). Penelitian ini dilaksanakan di SMA Muhammadiyah Kabanjahe Jalan Letjen Jamin Ginting No. 02. Sumber Mufakat, Kabanjahe, Kabupaten Karo, Provinsi Sumatera Utara pada semester genap tahun pelajaran 2019/2020. Waktu penelitian direncanakan pada bulan Maret sampai bulan April dan perlakuan diberikan tiga (3) kali tatap muka dalam pembelajaran penjaskes siswa kelas XI SMA Muhammadiyah Kabanjahe. Prosedur penelitian yang diterapkan dalam penelitian ini menggunakan rangkaian Action Research Classroom yang terdiri dari 1 siklus. Penelitian tindakan kelas (PTK) yang dilakukan pada siswa kelas XI SMA Muhammadiyah Kabanjahe Tahun Tahun Ajaran 2019/2020 pada masa Covid-19 terdapat peningkatan pada hasil belajar aktiviats fisik melalui model student facilitator and explainin. Peningkatan terjadi dengan menggunakan satu siklus diantaranya siklus memiliki persentase kelulusan klasikal siswa melampaui KKM adalah 93,5\% dengan rata-rata nilai 80,6, dan memiliki persentase kelulusan klasikal siswa melampaui KKM 75 dengan nilai rata-rata 80,6. Keberhasilan pembelajaran ditinjau dari perbandingan standar kelulusan klasikal pembelajaran penjaskes yang telah ditentukan sekolah dengan capaian pembelajaran yang dilakukan melalui pengukuran hasil belajar, sehingga hasil penelitian tindakan kelas (PTK) memiliki peningkatan yang signifikan. 


\section{PENDAHULUAN}

Pembelajaran Facilitator and Explaining disebut juga pembelajaran kelompok pembelajaran (group learning), yang merupakan istilah generik bagi bermacam prosedur instruksional yang melibatkan kelompok kecil yang interaktif. Siswa bekerja sama untuk menyelesaikan suatu tugas akademik dalam suatu kelompok kecil untuk saling membantu dan belajar bersama dalam kelompok mereka serta dengan kelompok yang lain. Pada umumnya dalam implementasi metode pembelajaran kooperatif, para siswa saling berbagi (sharing). Johnson dan Johnson, seperti yang dikutip Felder dan Brent (2007) memberikan gambaran yang lebih rinci dengan menyatakan pembelajaran Facilitator and Explaining adalah suatu pengajaran yang melibatkan siswa untuk berkerja sama dalam tim, menyelesaikan suatu tujuan bersama, dalam suatu kondisi meliputi unsur saling ketergantungan positif, tanggung jawab individu, interaksi tatap muka, penerapan keterampilan kolaboratif, dan proses kelompok. Dasar dari pembagian berbagai pembelajaran Facilitator and Explaining adalah pembagian kelompok bekisar 2-6 siswa pembelajar. Menurut Prince George's Country Public School (2011) adalah dengan 6 orang anggota kelompok dapat diberikan peran terhadap maisng-masing anggota kelompok sebagai berikut:

- Siswa pertama ditugasi sebagai fasilitator, yang perannya menjamin agar setiap anggota kelompok memberikan kontribusinya dan diskusi berjalan pada alur yang benar, ini biasanya dipilih siswa yang paling senior atau palingkompeten.

- Siswa kedua bertugas sebagai penulis, berperan menuliskan berbagai catatan penting yang mngepreksikan pemikiran kelompok, serta menyusun ihktisar final.

- Siswa ketiga sebagai presenter atau pembicara kelompok, berperan menyampaikan ikhtisar hasil karya kelompok kepada kelompok yang lebih besar (pleno kelas), dalam melakukan presentasi harus mewakili pemikiran kelompok dan bukan pandanganpribadinya.

- Siswa yang keempat sebagai manajer, pengelola bahan-bahan, bertugas mencari, membagikan, memilih bahan-bahan yang relevan, menyingkirkan bahan-bahan yang tidak relevan serta mengelola bahan-bahan yang diperlukan selama proses kerjakelompok.

- Siswa kelima berperan sebagai penjaga waktu, mencatat waktu yang telah digunakan dan mengingatkan anggota kelompok berapa lama lagi waktu yang tertinggal untuk penyelesiantugas.

Siswa yang keenam bertugas sebagai pengontrol, yang perannya mengontrol akurasi dan kejelasan pemikiran selama diskusi, dapat juga mengecekcatatan yang tertulis atau dilaporkan oleh penulis, mengontrol jalannya diskusi agar tetap pada jalur yang benar. Langkah-langkah Model Student Facilitator and Explaining dapat dilakukan dengan cara: 1) Guru menyampaikan kompetensi yang ingin dicapai/ KD, 2) Guru mendemonstrasikan/ menyajikan garis-garis besar materi pembelajaran, 3) Memberikan kesempatan siswa untuk menjelaskan kepada siswa lainnya, misalnya melalui bagan/ peta konsep. Hal ini bisa dilakukan secara bergiliran, 4) Guru menyimpulkan ide/ pendapat dari siswa, 5) Guru menerangkan semua materi yang disajikan saat itu.

Pembelajaran kooperatif Student Facilitator and Explaining merupakan salah satu tipe pembelajaran kooperatif yang menekankan pada struktur khusus yang dirancang untuk mempengaruhi pola interaksi siswa dan memiliki tujuan untuk meningkatkan penguasaan akademik. Model pembelajaran Student Facilitator and Explaining dapat meningkatkan antusias, motivasi, keaktifan dan rasa senang siswa dapat terjadi. Sehingga sangat cocok di pilih guru untuk digunakan pada pembelajaran bahasa. Karena pada model Student Facilitator and Explaining atau bermain peran ini suatu cara penguasaan siswa terhadap beberapa keterampilan diantaranya keterampilan berbicara, keterampilan menyimak, keterampilan pemahaman pada teks bacaan, dan keterampilan seni dalam memerankan seorang tokoh sesuai konteks bacaan dalam keadaan riang. (Prasetyo,2001). Aktivitas fisik adalah melakukan pergerakan anggota 
tubuh yang menyebabkan pengeluaran tenaga yang sangat penting bagi pemeliharaan kesehatan fisik, mental, dan mempertahankan kualitas hidup agar tetap sehat dan bugar sepanjang hari. Jenis aktivitas fisik yang dapat dilakukan sehari-hari yaitu: belajar, berjalan kaki, berkebun, kerja di taman, mencuci pakaian, mencuci mobil, mengepel lantai, naik turun tangga, dan lainnya. Sedangkan jenis olahraga yang bisa dilakukan yaitu: push-up, lari ringan, bermain bola, berenang, senam, bermain tenis, yoga, fitness dan angkat beban/berat, atau aktivitaslainnya. Melakukan aktivitas fisik dilakukan secara teratur paling sedikit 30 menit dalam sehari, dapat meningkatkan kesehatan jantung, paru-paru serta alat tubuh lainnya. Jika kegiatan ini dilakukan setiap hari secara teratur, terukur, maju berkelanjutan maka dalam waktu 3 bulan ke depan akan terasa hasilnya.

\section{METODE}

Penelitian ini merupakan penelitian tindakan (Action Research) yang dikebangkan pada aspek pendidikan yaitu menjadi Penelitian Tindakan Kelas (PTK). Model tindakan Action Research yang digunakan adalah Model Spiral dari Kemmis dan Taggart. Model Spiral dari Kemmis dan Taggart adalah model yang realisasinya menggunakan istilah Plan, Act, Observe, dan Reflect (Suharsaputra, 2018). Penelitian ini dilaksanakan di SMA Muhammadiyah Kabanjahe Jalan Letjen Jamin Ginting No. 02. Sumber Mufakat, Kabanjahe, Kabupaten Karo, Provinsi Sumatera Utara pada semester genap tahun pelajaran 2019/2020. Waktu penelitian direncanakan pada bulan Maret sampai bulan April dan perlakuan diberikan tiga (3) kali tatap muka dalam pembelajaran penjaskes siswa kelas XI SMA Muhammadiyah Kabanjahe. Prosedur penelitian yang diterapkan dalam penelitian ini menggunakan rangkaian Action Research Classroom yang terdiri dari 1 siklus. Berikut prosedur atau langkah-langkah penelitian yang diterapkan:

- Tahap Perencanaan

Adapun langkah-langkah yang ditempuh dalam perencanaan 1 adalah sebagai berikut:

- Tim peneliti melakukan analisis kurikulum untuk mengetahui kompetensi dasar dalam pembelajaran pendidikan jasmani.

- Membuat rencana pembelajaran dengan mengacu pada tindakan yang diterapkan dalam PTK.

- Menetapkan instrumen yang digunakan dalam pembelajaran terkait materi aktivitasfisik.

- Menyiapkan media yang diperlukan untuk membantu prosespembelajaran.

- Rencana pengembangan materi pembelajaran aktivitasfisik.

- Tahap Pelaksanaan

Tahap pelaksanaan kegiatan yang dilakukan adalah melaksanakan rangkaian belajar mengajar sesuai langkah-langkah sebagaimana berikut ini:

- Menjelaskan cara konsep dasar aktivitas fisik dan mengarahkan siswa pada penggunaan model pembelajaran mengajar Student Facilitator and Explaining, diantaranya adalah membai kelompok menjadi 6 bagian dan memberikan setiap kelompok sub materi yang akan di bahas yaitu: Pola Aktivitas Fisik Setiap Hari, Pola dan Kebiasaan Makan, (3) Pola Istirahat, Penyakit, Kebiasaan Buruk bagi Kesehatan, Pengaturan perencanaan Pola Makan dengan Menghitung Kebutuhan Kalori Harian Tubuh.

- Setelah kelompok terbagi, siswa diminta untuk berdiskusi dari sumber buku dan referensi lain jika ada.

- Diskusi kelompok dapat dilanjutan setelah jam pulang dan menjadi tugas untuk membuat makalah dan powerpoint persentase setiap kelompok.

- Tahap Observasi

Pada tahap ini dilakukan observasi terhadap pelaksanaan tindakan yang menggunakan catatan dan menyesuaikan keberhasilan dengan instrumen penilaian materi aktivitas fisik. Guru menggunakan instrumen penilaian afektif dalam memberikan penilaian diskusi siswa 
dan mencatat hal berkembang sesuai kondisi belajar di kelas. Tahap ini difokuskan pada pengamatan terhadap siswa tentang pelajaran dan materi yang diajarkan serta kegiatan belajar selama pembelajaran berlangsung. Tahap observasi ini merupakan penilaian awal untuk mengetahui perkembangan yang dialami siswa selama tahap I.

- Tahap Refleksi

Refleksi merupakan pengkajian proses pembelajaran terkait penilaian hasil belajar. Tahap observasi dikumpulkan dan dianalisis untuk diperoleh hasil yang dapat disimpulkan dari tindakan yang dilakukan dari hasil tes hasil belajar I, hasil refleksi ini digunakan sebagai dasar untuk tahap perencanaan siklus II apabila pada siklus I hasil yang di inginkan belumtuntas.

Sumber data diperoleh berdasarkan variabel dalam penelitian ini terdiri dari dua (2) macam variabel yang terdiri dari 1 variabel bebas (independent) dan 1 variabel terikat (dependent), sebagaimana penjelasan berikut:

- Variabel bebas (independent) adalah model pembelajaran Student Facilitator and Explaining yang terdiri dari prosedur pelaksanaan kegiatan dan sebagai pemberi pengaruh terhadap objek yang akandirubah.

- Variabel terikat (dependent) adalah hasil belajar Aktivitas Fisik yang akan dilihatperubahannya.

Subjek dalam penelitian ini adalah seluruh siswa kelas XI SMA Swasta Muhammadiyah Kabanjahe tahun Ajaran 2019/2020 yang berjumlah 31 orang. Dengan jumlah siswa laki-laki sebanyak 16 orang dan jumlah siswa perempuan sebanyak 15 orang.

Teknik perolehan data dalam proses penelitian yang dilakukan adalah peneliti melakukan penilaian dan tes awal berdasarkan aspek kognitif, psikomotor dan afektif terkait materi pembelajaran dengan instrumen penilaian materi aktiviats fisik. Kegiatan penelitian selanjutnya melaksanakan program pembelajaran penjaskes sesuai dengan model pembelajaran Student Facilitator and Explaining. Tahap akhir, peneliti melakukan pengumpulan data hasil belajar aktivitas fisik yang meliputi aspek kognitif, psikomotor dan afektif (samadengan tes awal) dengan instrumen yang dibuat peneliti dan disesuaikan dengan ketentuan yang berlaku pada guru penjasorkes dan sekolah.

Bentuk penilaian hasil belajar aktivitas fisik meliputi penilaian kognitif, psikomotor, dan afektif, berikut bentuk penilaian yang akan dilakukan peneliti:

Uji validitas dan reliabilitas Instrumen Penilaian Hasil Belajar Kognitif

- Uji validasi (tepat) instrumen penilaian kognitif dilakukan menggunakan teknik validasi isi berdasarkan rasional yang telah ditetapkan oleh Kementerian Pendidikan dan Kebudayaan (Kemendikbud) Republik Indonesia sebagaimana tertera pada Buku Bahan Ajar penjaskes Kurikulum 2013 Tahun Revisi 2017 (Sudijono, 2012).

- Uji reliabilitas (tetap) instrumen penilaian kognitif dilakukan menggunakan teknik reliabilitas lembaga negera yang telah ditetapkan oleh Kementerian Pendidikan dan Kebudayaan (Kemendikbud) Republik Indonesia sebagaimana tertera pada Buku Bahan Ajar penjaskes Kurikulum 2013 Tahun Revisi 2017 (Sudijono, 2012).

Uji validitas dan reliabilitas Instrumen Penilaian Hasil Belajar Psikomotorik

- Uji validasi (tepat) instrumen penilaian Psikomotorik dilakukan menggunakan teknik validasi isi berdasarkan rasional yang telah ditetapkan oleh Kementerian Pendidikan dan Kebudayaan (Kemendikbud) Republik Indonesia sebagaimana tertera pada Buku Bahan Ajar penjaskes Kurikulum 2013 Tahun Revisi 2017 (Sudijono, 2012).

- Uji reliabilitas (tetap) instrumen penilaian Psikomotorik dilakukan menggunakan teknik reliabilitas lembaga negera yang telah ditetapkan oleh Kementerian Pendidikan dan Kebudayaan (Kemendikbud) Republik Indonesia sebagaimana tertera pada Buku Bahan Ajar penjaskes Kurikulum 2013 Tahun Revisi 2017 (Sudijono, 2012).

Proses reduksi data dilakukan dengan cara menyeleksi siswa, menyederhanakan dan mentransformasikan data yang telah disajikan dalam transkip catatan lapangan. Kegiatan 
reduksi data ini bertujuan untuk melihat kesalahan atau kekurangan siswa dalam pelaksanaan tes dan tindakan apa yang dilakukan untuk perbaikan kesalahan tersebut. Dalam kegiatan ini data yang diperoleh dari hasil belajar, Jika indikator memiliki kriteria kompleksitas tinggi, daya dukung tinggi dan intake siswa sedang, maka nilai KKM nya adalah :

- Mendapat nilai Sangat Baik, jika skor antara $=90-100$

- Mendapat nilai Baik, jika skor antara $=80-89$

- Mendapat nilai Cukup, jika skor antara $=70-79$

- Mendapat nilai Kurang, jika skor antara $=60-69$

- Mendapat nilai Kurang Sekali, jika skor $=0$ - 59

\section{HASIL \& PEMBAHASAN}

Penelitian Tindakan Kelas (PTK) pada siswa kelas XI SMA Muhammadiyah Tahun 2019/2020 terhadap materi aktivitas fisik dilakukan dengan 2 kali pertemuan yaitu pada tanggal 16 dan 21 Mei 2020. Pelaksanaan PTK dilakukan dengan gaya mengajar facilitator and explaining yaitu gaya mengajar yang dilakukan dengan memberikan materi aktivitas fisik, kemudian diskusi, dan penilaian. Kegiatan penelitian tindakan kelas yang dilaksanakan peneliti melalui online atau dalam jaringan (daring) terhadap materi aktivitas fisik dengan menggunakan model pembelajaran Student Facilitator and Explaining pada siswa kelas XI SMA Muhammadiyah Kabanjahe Tahun Ajaran 2019/2020. Data diperoleh pada siswa diantaranya adalah data awal (pre test) data hasil observasi siklus I. Pemberlakukan pembelajaran daring ditetapkan atas dasar keputusan Menteri Pendidikan dan Kebudayaan (Kemdikbud), Gubernur Provinsi Sumatera Utara, Bupati Tanah Karo, dan Keputusan Kepala Sekolah.

Pelaksanaan pembelajaran daring materi aktivitas fisik dilaksanakan sejak 13 Mei 2020 hingga 30 Mei 2020 dikarenakan pademi corona virus desease 2019 atau di kenal Covid-19. Materi yang disampaikan guru dilakukan melalui aplikasi zoom dengan memberikan penjelasan terhadap materi aktivitas fisik. Materi aktivitas fisik terdapat pada buku paket siswa sehingga capaian pembelajaran harus dapat dicapai berdasarkan pedoman buku penjaskes. Data penelitian yang diperoleh pada kegiatan penelitian adalah hasil penilaian mulai dari pertemuan 1 (satu) hingga pertemuan 2 (dua). Berikut data penelitian yang diperoleh dalam tabel berikut:

Tabel 1. Data Penelitian

\begin{tabular}{ccccccc}
\hline \multirow{2}{*}{ Hasil Tes } & Siswa Yang & \multirow{2}{*}{ Persentase } & $\begin{array}{c}\text { Siswa Yang } \\
\text { Tidak Tuntas }\end{array}$ & Persentase & Nilai (Rata-Rata) & Keterangan \\
Tes Awal & 4 & $12,9 \%$ & 27 & $87,1 \%$ & 65,2 & Belum Tuntas \\
Tes Akhir & 29 & $93,5 \%$ & 2 & $6,5 \%$ & 80,6 & Tuntas \\
\hline
\end{tabular}

Berdasarkan data penelitian diketahui bahwa siswa kelas XI dengan jumlah 31 orang dan menjadi subjek penelitian diperoleh data 4 orang siswa (12,9\%) memiliki ketuntasan belajar dan 27 orang siswa $(87,1 \%)$ siswa belum memiliki tuntas belajar. Pelaksanan penelitian tindakan kelas pada siklus I diperoleh data 29 orang siswa $(93,5 \%)$ tuntas belajar dan 2 orang $(6,5 \%)$ belum tuntas belajar.

Pelaksanaan penelitian dilakukan berdasarkan kondisi yang terjadi pada siswa kelas XI SMA Muhammadiyah Kabanjahe Tahun Ajaran 2019/2020 melalui teknik perolehan data secara virtual dengan menyampaikan pembuka pembelajaran dan berikutnya pemberian tes kognitif melalui file yang dikirim melalui Whatsapp Group. Data tahap ini disebut sebagai data pre test yang kemudian akan dijadikan sebagai pembanding setelah siswa menerima model pembelajaran Student Facilitator and Explaining. Berikut data pre test (tes awal) yang diperoleh:

Tabel 2. Hasil Tes Awal

\begin{tabular}{cccc}
\hline Hasil Tes & Keterangan & Jumlah Siswa & Persentase \\
\hline
\end{tabular}




\begin{tabular}{lccc} 
Skor $<72$ & Tidak Tuntas & 27 & $87,1 \%$ \\
Skor $\geq 72$ & Tuntas & 4 & $12,9 \%$ \\
\hline
\end{tabular}

Berdasarkan data hasil tes awal materi aktivitas fisik dapat disimpulkan bahwa siswa berjumlah 31 orang memiliki $87,1 \%$ (27 orang) belum tuntas pada hasil belajar aktivitas fisik dan siswa yang tuntas 12,9\% (4 Orang) sehingga dapat disimpulkan hasil belajar aktivitas fisik belum mencapai hasil belajar yang diharapakan mencapai Kriteria Ketuntasan Minimum (KKM)75.

Pelaksanaan perencanaan pada siklus I merupakan tahap awal upaya pemberian solusi terhadap hasil belajar aktivitas fisik yang belum memiliki ketuntasan klasikal yaitu $80 \%$ artinya seluruh siswa di kelas XI yang menjadi subjek penelitian harus memiliki ketuntasan klasikal 2425 orang sehingga siswa yang mengikuti materi dapat dilaksanakan dan mencapai kompetensi pembelajaran Pnejasorkes. Perencanaan pada suklus I dilaksanakan sebagai berikut:

- Tim peneliti melakukan analisis kurikulum untuk mengetahui kompetensi dasar dalam pembelajaran pendidikan jasmani pada masacovid-19.

- Membuat rencana pembelajaran dengan mengacu pada tindakan yang diterapkan dalam PTK, yaitu pembelajaran aktivitasfisik.

- Menetapkan instrumen yang digunakan dalam pembelajaran terkait materi aktivitasfisik.

- Menyiapkan media yang diperlukan untuk membantu prosespembelajaran.

- Rencana pengembangan materi pembelajaran aktivitas fisik.

Pelaksanaan pembelajaran dilakukan dengan tahapan pembelajaran penjaskes secara online yang meliputi pembuka (menyapa siswa) melalui aplikasi zoom, inti kegiatan dengan memberkan materi belajar, dan terakhir adalah penutup dengan memberikan pengayaan materi ajar. pelaksanaan kegiatan yang demikian dilakukan pada jangka waktu \pm 5-10 menit. Pelaksanaan tindakan dalam penelitian ini merupakan tindakan tahap awal untuk memberikan kegiatan kepada siswa berupa metode belajar Facilitator And Explaining. Teknik belajar Facilitator And Explaining yang diterapkan tahap tindakan I pada pandemi covid-19 ini dilakukan dengan meminta siswa memberikan penjelasan kembali terkiat materi aktivitas fisik. Hasil dari penjelasan siswa kemudian dilanjutkan dengan diskusi tentang materi aktivitas fisik. Berdasarkan hasil diskusi tersebut, maka rencana pembelajaran tetap menggunakan siklus I karena tidak memungkitkan menggunakan bentuk aktivitas lain pada masa covid-19 ini.

Observasi penelitian tahap I dilakukan dengan menggunakan instrumen penilaiah hasil belajar yang meliputi Kognitif. Data siklus I ini diperoleh melalui proses pembelajaran yang dilakukan siswa terhadap materi aktivitas fisik dengan menggunakan metode Facilitator And Explaining. Pelaksanaan observasi dilakukan oleh guru untuk mengamati setiap proses yang dilakukan siswa yang meliputi teknik pelaksanaan aktivitas fisik dan pengetahuan serta tingkah laku siswa selama pembelajaran. Hasil observasi siswa pada siklus I diketahui kemampuan siswa terjadi peningkatan yaitu:

Tabel 3. Hasil Tes Akhir

\begin{tabular}{lccc}
\hline Hasil Tes & Keterangan & Jumlah Siswa & Persentase \\
Skor $<72$ & Tidak Tuntas & 2 & $6,5 \%$ \\
Skor $\geq 72$ & Tuntas & 29 & $93,5 \%$ \\
\hline
\end{tabular}

Data diperoleh pada siklus I yaitu siswa mengalami peningkatan hasil belajar aktivitas fisik dengan jumlah 29 orang siswa $(93,5 \%)$ atau 25 siswa mengalami capaian hasil belajar. Pelaksanaan siklus I memiliki pengaruh terhadap peningkatan pembelajaran yaitu dengan menggunakan gaya Facilitator And Explaining, dengan penjelasan yang terlebih dahulu diberikan kepada siswa mampu memberikan dampak pada kemudahan dalam melaksanakan pembelajaran. 
Refleksi terkait pembelajaran pada siklus I diperoleh kajian terhadap proses pembelajaran yang dianalisis berdasarkan temuan-temuan pelaksanaan dan observasi. Refleksi siklus I dapat diuraikan sebagai berikut:

- Kekurangan yang ditemukan pada siklus I :

- Siswa belum sepenuhnya menguasai teknik aktivitas fisik, sehingga membutuhkan proses pembelajaran lanjutan untuk memberikan dampak yang signifikan.

- Guru tidak memberikan kesempatan siswa untuk berdiskusi pada proses pembelajaran, dan fokus pada bagian latihan tahapan.

- Gaya mengajar Facilitator and Explaining diperlukan kolaborasi dengan metode lainnya agar pembelajaran lebih aktif dalam berinteraksi.

- Keberhasilan yang ditemukan pada siklus I:

- Kegiatan awal pembelajaran materi aktivitas fisik dapat dilakukan dengan baik seperti pemberian materi secara menyeluruh, pemanasan, dan peregangan sebelum memulai pembelajaran.

- Pembelajaran yang diterapkan tepat saat menggunakan gaya mengajar Facilitator and Explaining yaitu membagi teknik-teknik pelaksanaan aktivitas fisik menjadi tiga bagian yang diantaranya terdiri dari teknik yang mudah, sedang, dan sampai yang kompleks.

- Guru memberikan kesempatan siswa untuk berdiskusi dan mengevaluasi pembelajaran serta memberikan pendapat mengenai pelaksanaan pembelajaran selanjutnya. Kegiatan ini merupakan upaya mengetahui antusia siswa dalam pembelajaran sehingga dapat menilai secara langsung bahwa pembelajaran terlaksana dengan baik.

- Peralatan yang dibutuhkan tersedia dengan baik tanpa mengalamui masalah yang berarti.

Penelitian yang dilaksanakan oleh peneliti dilakukan melalui virtual atau dalam jaringan (daring) sehingga perkembangan mengenai pembelajaran seutuhnya tidak dapat dilakukan oleh pengamatan langsung terkait perubahan-perubahan yang terjadi. Pada pertemuan materi aktivitas fisik kelas XI SMA Muhammadiyah Kabanjahe, peneliti mendapatkan rata-rata nilai 56 melalui penilaian kognitif. Penerapan gaya mengajar facilitator and explaining dilaksanakan setelah penilaian pertama (pretst). Gaya mengajar yang diterapkan melalui pembelajaran daring tidak diterapkan sebagaimana mestinya yaitu: 1) Guru menyampaikan kompetensi yang ingin dicapai/KD, 2) Guru mendemonstrasikan/menyajikan garis-garis besar materi pembelajaran, 3) Memberikan kesempatan siswa untuk menjelaskan kepada siswa lainnya, misalnya melalui bagan/peta konsep. Hal ini bisa dilakukan secara bergiliran, 4) Guru menyimpulkan ide/pendapat dari siswa, 5) Guru menerangkan semua materi yang disajikan saat itu. Maka pelaksanaan gaya mengajar masa Covid-19 yaitu: 1) Guru menyampaikan kompetensi yang ingin dicapai/ KD, 2) Guru menjelasakan garis-garis besar materi pembelajaran, 3) Memberikan kesempatan siswa untuk memberikan pendapat secara bergiliran, 4) Guru menyimpulkan ide/ pendapat dari siswa, 5) Guru menerangkan semua materi yang disajikan saat itu.

Waktu penerapan pembelajaran diterapkan secara terbatas atau tidak sesuai dengan waktu yang ditetapkan yaitu waktu sebelum Covid-19 adalah 40 menit/jam, dan pada masa Covid-19 disesuaikan dengan kemampuan siswa yaitu 10-40 menit per satu kali pertemuan. Berdasarkan waktu pelaksaan pembelajaran tersebut maka disimpulan bahwa capaian kompetensi siswa akan sulit diperoleh dan diperlukan pertemuan lebih lanjut yang lebih intensif. Hasil capaian belajar siswa selanjutnya diterapkan setelah pemberian materi yakni dihari kedua, hal ini dikarenakan waktu pembelajaran pada satu materi tidak dapat diterapkan dalam jangka waktu yang lama mengigat sekolah memberikan batasan pertemuan, sedangkan materi yang telah ditetapkan dalam satu semeter harus dicapai sesuai kalender akademik masa Covid-19. Hasil penilaian kedua diperoleh data nilai rata-rata 80,6 dan berdasarkan situasi Covid-19 maka siswa dituntaskan belajarnya, dan dilanjutkan pada materi lain. Hasil penilaian tersebut kemudian merupakan data penelitian yang dapat disimpulkan yaitu gaya mengajar facilitator and explaining dapat memberikan peningkatan pada hasil belajar hasil belajar materi aktivitas fisik. 
Capaian yang terjadi hanya pada siklus I diperoleh hasil analisis bahwa siswa yang mengerjakan soal kognitif dilaksanakan secara langsung atau dapat melihat referensi, siswa tidak terawasi dalam mengerjakannya, dan kondisi pengerjaan memiliki ketenangan dalam rumah masingmasing atau tanpa desakan dari guru.

\section{SIMPULAN}

Penelitian tindakan kelas (PTK) yang dilakukan pada siswa kelas XI SMA Muhammadiyah Kabanjahe Tahun Tahun Ajaran 2019/2020 pada masa Covid-19 terdapat peningkatan pada hasil belajar aktiviats fisik melalui model student facilitator and explainin. Peningkatan terjadi dengan menggunakan satu siklus diantaranya siklus memiliki persentase kelulusan klasikal siswa melampaui $\mathrm{KKM}$ adalah 93,5\% dengan rata-rata nilai 80,6, dan memiliki persentase kelulusan klasikal siswa melampaui KKM 75 dengan nilai rata-rata 80,6. Keberhasilan pembelajaran ditinjau dari perbandingan standar kelulusan klasikal pembelajaran penjaskes yang telah ditentukan sekolah dengan capaian pembelajaran yang dilakukan melalui pengukuran hasil belajar, sehingga hasil penelitian tindakan kelas (PTK) memiliki peningkatan yang signifikan.

\section{DAFTAR PUSTAKA}

Azmin, N. H. (2016). Effect of the Jigsaw-Based Cooperative Learning Method on Student Performance in the General Certificate of Education Advanced- Level Psychology: An Exploratory Brunei Case Study. International Education Studies. 9(1): 91-106.

Azwar, S. (2014). Reliabilitas dan Validitas. Yogyakarta: Pustaka Pelajar.

Creswell, J. W. (2014). Research Design: Pendekatan Kualitatif, Kuantitatif, dan Mixed. Yogyakarta: Pustaka Pelajar.

Fenanlampir, A., \& Faruq, M. M. (2015). Tes dan Pengukuran dalam Olahraga. Yogyakarta: Andi.

Gunawan, M. A. (2013). Statistik untuk Penelitian Pendidikan. Yogyakarta: Parama Publishing. Huda, M. (2014). Model-Model Pengajaran dan Pembelajaran. Yogyakarta: Pustaka Pelajar.

Komarudin. (2016). Penilaian Hasil Belajar Pendidikan Jasmani dan Olahraga. Bandung: Remaja Rosdakarya.

Ling, J., \& Catling, J. (2012). Psikologi Kognitif. Terjemahan Noormalasari Fajar Widuri. Jakarta: Erlangga.

Mosston, M., \& Ashworth, S. (2008). Teaching Physical Education._: First Online Edition.

Muhajir. (2007). Pendidikan Jasmani Olahraga dan Kesehatan. Jakarta: Erlangga

Olympia, L., Eva, P., Panagiotis, A., \& Argyris, K. (2014). Proposal of a physical education program with multicultural elements in the Secondary Education and evaluation of student satisfaction. International Journal of Education and Research. 2(12): 165-180.

Purwanto, M. N. (2012). Prinsip-Prinsip dan Teknik Evaluasi Pengajaran. Bandung: Remaja Rosdakarya.

Prasetya. (2012). Meningkatkan Keterampilan Menyusun Instrumen Hasil Belajar Berbasis Modul Interaktif Bagi Guru-Guru IPA SMP N Kota Magelang. Journal of Educational Research and Evaluation. 1 (2).

Rahayu, E. T. (2013). Strategi Pembelajaran Pendidikan Jasmani. Bandung: Alfabeta.

Rahyubi, H. (2014). Teori-Teori Belajar dan Aplikasi Pembelajaran Motorik. Bandung: Nusa Media.

Rosdiani, D. (2013). Perencanaan Pembelajaran dalam Pendidikan Jasmani dan Kesehatan. Bandung: Alfabeta.

Sudijono, A. (2012). Pengantar Evaluasi Pendidikan. Jakarta: Rajawali Pers.

Sudira, M. P. (2006). Kurikulum Tingkat Satuan Pendidikan SMK. Jakarta: Departemen Pendidikan Nasional.

Sugiyono. (2011). Metode Penelitian Kombinasi (Mixed Methodes). Bandung: Afabeta. 
Syah, M. (2013). Psikologi Belajar. Jakarta: Raja Grafindo Persada.

Tran, V. D. (2014). The Effects of Cooperative Learning on the Academic Achievement and Knowledge Retention. International Journal of Higher Education. 3(2): 131-140.

Uno, H. B., \& Mohamad, N. (2011). Belajar dengan Pendekatan PAILKEM. Jakarta: Bumi Aksara.

Usman, H., \& Akbar, R. P. S. (2011). Pengantar Statistik. Jakarta: Bumi Aksara.

Warsono \& Hariyanto. (2014). Pembelajaran Aktif. Bandung: Remaja Rosdakarya. 